\title{
Dr. Wenn Lawson: A szenvedélyes elme - Hogyan tanulnak az autisták?
}

\author{
Nagyné Dézsi Erika
}

\author{
Eszterházy Károly Egyetem Pedagógiai Kar \\ Neveléstudomány MA hallgatója \\ nagynedezsierika@gmail.com
}

Wenn Lawson (2018): A szenvedélyes elme. Hogyan tanulnak az autisták? Budapest: Geobook Hungary Kiadó. ISBN 9786155015441

DOI: 10.37205/TEL-hun.2020.3-4.09

Dr. Wenn Lawson

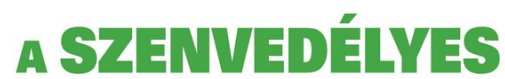

ELMME

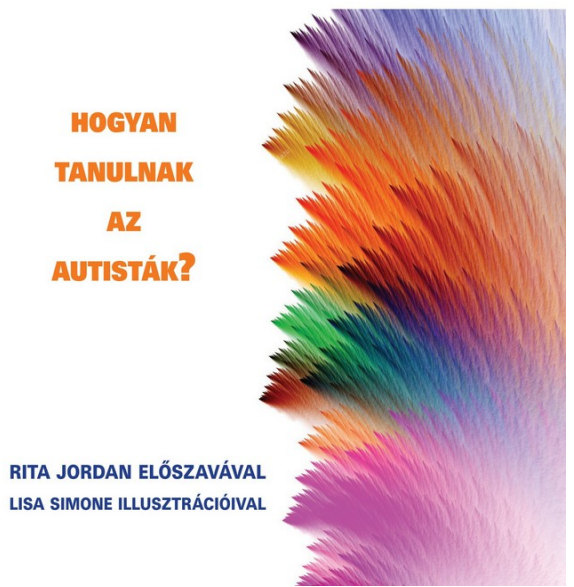

Az autizmus spektrumzavar újszerü megértéséhez nyújthat segítséget a bármely korú gyermekek nevelésében részt vevők számára: A szenvedélyes elme címü könyv, melyet 2011-ben adtak ki először Angliában. A mü eredeti címe: The passionate mind. Hazánkban 2018-ban a Geobook Hungary kiadásában jelent meg.

$\mathrm{Az}$ autizmus spektrumzavar egy speciális neurobiológiai fejlődési állapot, nagyrészt genetikailag meghatározott, jellegzetes neuroanatómiai, neurokémiai eltérésekkel. Jellemzően a gyermek kommunikációs képességében, nehezen alakuló vagy hiányzó szociális kapcsolataiban - nem elfogadott viselkedési formában -, valamint szte-

reotip cselekvéseiben nyilvánul meg (autisztikus triász/diád). Összességében olyan élethosszig tartó, idegrendszeri fejlődési állapot, amely etiológiai hátterét és jellegzetes viselkedéses mintázatait tekintve egyaránt heterogén. A spektrum szó arra utal, hogy ez az állapot egy multidimenzionális skála mentén értelmezheto, amelynél az életkor, az autizmus súlyossága, az intelligenciaszint, a beszéd valamint a beszédértés szintje, a személyiség és a környezeti hatások egyaránt befolyásoló tényezők lehetnek (Emberi Erőforrások Minisztériuma, 2020). Fombonne 
(2005) szerint a témában végzett nemzetközi kutatások adataiból az derült ki, hogy világszerte folyamatosan nő a pervazív fejlődési zavarokkal élő diagnosztizált gyermekek aránya. Az adatok alapján valószínűsíthetően igaz ez a gyermekkori autizmus prevalenciájára is. Az ezredforduló elején végzett felmérések szerint ugyanis az autizmus spektrum rendellenességekkel élők száma a legoptimistább becslések szerint is a populáció közel 0,6\%-át érinti. Azt is érdemes figyelembe venni, hogy az évek során növekvő számokat nagyrészt a diagnosztikai koncepciók és kritériumok megváltozása, valamint az egyre pontosabb azonosítás magyarázza (Fombonne, 2005).

A Bognár Virág, Bíró Andrea és Marossy-Dévai Zita (2009) által készített hazai kutatás rávilágít, hogy az utóbbi években egyre többször találkozhatnak autizmus spektrum zavarral (ASD) élő gyermekkel hazánkban is a szakemberek. Az Autisták Országos Szövetsége és a Jelenkutató Alapítvány jóvoltából a 2000-es évek elején megvalósult Országos Autizmus Kutatás eredményeiből kiderült, hogy a 15 évesnél fiatalabb, gyermekkorú népességen belül 10 ezer lakosra 2000-ben 5,69, 2007-ben 16,03 ASD-vel élő járóbeteg jutott. A vizsgált időszakban évente a 4-5-6 évesek köréből került ki a legtöbb járóbeteg. A 15-19 éves korcsoportban pedig második csúcs figyelhető meg. Ebben a korban elsősorban az Asperger-szindróma diagnózisok számának serdülőkorra tehető intenzívebbé válása figyelhető meg. Ezt az életkort követően fokozatosan csökken a diagnosztizáltak száma, de figyelemre méltó, hogy 24-25 éves korig is számottevő marad (Bogár, Bíró \& MarossyDévai, 2009). Mindezt alátámasztják az Oktatási Hivatal Közoktatási információs rendszerében (KIR) olvasható adatok is. A hivatal információi szerint ugyanis a köznevelési rendszerben mostanra közel 6000 autista gyermeket tartanak nyilván. Ebből az integrált nevelésben, oktatásban részt vevő gyermekek száma 141 fő (Oktatási Hivatal, 2018). Az Autisták Országos Szövetségének becslése szerint ma Magyarországon minden száz emberből egy autizmus spektrum zavarban érintett. Ami azt jelenti, hogy minimum 100.000 autista személy él az országban.

E statisztikai adatok alapján jól látható, hogy az autizmus olyan téma, mellyel érdemes és szükséges foglalkozni a gyógypedagógusokon, illetve egészségügyi dolgozókon kívül a köznevelésben dolgozó pedagógusoknak is. Ezt támasztja alá az is, hogy az autizmus Magyarországon 2003. március 1-jétől önálló fogyatékossági kategória lett.

A szenvedélyes elme. Hogyan tanulnak az autisták? című könyv szerzője pszichológus, a Brit Pszichológiai Társaság tagja. Jelenleg a Birminghami Egyetem au- 
tizmus mesterszakának tanára. Több autistákat támogató egyesület elnökségi tagja. Tanácsadóként vesz részt az Autism CRC (Ausztrália) munkájában. A szerző személyes érintettségét jól mutatja, hogy 42 éves korában őt magát is diagnosztizálták autizmussal, ADHD-val, dyspraxiával és egyéb tanulási nehézségekkel, illetve négy gyermeke közül a legfiatalabb fia, valamint két unokája szintén autista. 1998-ban adta ki első, autizmusról szóló könyvét Élet az üveg mögött címmel. Azóta számos autistáknak, illetve autistákról szóló mủve jelent meg.

A könyv 238 oldal terjedelmű a függelékekkel és a tárgymutatóval együtt. Illusztrációját egy szintén autista művész Liza Simone készítette. Az előszót Rita Jordan írta.

A szenvedélyes elme az autizmus témájához a pszichológiai, a gyógypedagógiai és a pedagógiai tudományterületek oldaláról közelít összegyüjtve az egyes területeken a témához kapcsolódóan rendelkezésre álló tudást. A könyv alapját a szerző saját $\mathrm{PhD}$ dolgozata adta, azonban a közérthetőség, valamint a megértés segítése érdekében számos saját példával egészítette ki az eredeti szöveget. Kulcsszava a megértés. Műfaját tekintve a szaktudományos és ismeretterjesztő könyvek között helyezkedik el. Nyelvezete egyszerre tudományos és olvasmányos, ezáltal jól érthető azok számára is, akik kevésbé jártasak a gyógypedagógia és a pszichológia világában. Habár stílusa az ismeretterjesztő művekével rokon, szaktudományos igényét támasztja alá a hivatkozások és a felhasznált szakirodalmak minősége. A könyv tíz fejezetből áll, valamint a végén öt függeléket és egy tárgymutatót tartalmaz. A szerző a könyv első fejezeteiben kritikusan ismerteti az autizmus eddigi kognitív elméleteit rávilágítva azok erősségeire és gyengeségeire, a második részben pedig a saját életéből vett tapasztalatok, valamint a munkája során szerzett ismeretek alapján felvázol egy az eddigiektől gyökeresen eltérő új autizmusmodellt.

A szerző az első fejezetben őszintén ír arról, hogyan élte meg, amikor megkapta a diagnózist: autista. Leírja, miért használja szívesebben az „autizmus spektrum zavar” kifejezés helyett az „autizmus spektrum képességeltérés” elnevezést. Továbbá részletezésre kerülnek az autizmus jelenlegi értelmezéseinek alapjai, a szerző magyarázza ezek logikáját. Majd az értelmezésekhez kapcsolódóan kifejti ezen az értelmezések alapvető problémáit.

A második fejezet átfogó összefoglalót ad arról, hol tart napjainkban az autizmus kutatása. Külön kitér olyan részletekre is, mint az autizmus nemek közti megoszlási aránya és az előfordulás gyakorisága. Érdekes, a szakirodalomban ke- 
véssé megjelenő aspektusból is szemlélteti az autizmust: részletesen ír arról, hogyan látják tüneteiket maguk az autizmussal élők. Ez segítséget ad azoknak, akik szeretnék jobban megérteni, mi zajlik adott helyzetekben egy autizmussal élő egyénben. A szemléletes ábrákkal illusztrált fejezetben olvashatunk arról is, miben különböznek például a tanulási stílus tekintetében az autisták a neurotipikus emberektől. Hogyan éli meg egy autista az iskolai csoportos feladatokat, valamint milyen érzékszervi eltérések okozzák azt, hogy másképp reagálnak bizonyos érzékszervi jelenségekre. A szerző rávilágít az autizmus eddigi megközelítésének hiányosságaira, és utal arra, hogy a deviánsnak minősítő szemlélet helyett helyesebb lenne az értékekre építeni, és a kiteljesedés lehetőségét támogatni.

A harmadik fejezet az autizmus spektrum kognitív elméleteivel foglalkozik. A szerző először olyan alapfogalmakat tisztáz, mint például a kogníció, a gondolkodás, az észlelés és a figyelem, melyek ismerete elengedhetetlen az elméletek megértéséhez. Továbbiakban feltáró képet ad az autizmus spektrum kogníció elméleti problematikájáról. A fejezet érintőlegesen foglalkozik még a napjainkban elfogadott egyéb, nem kognitív elméletekkel is. Itt utal a szerző a könyv végén lévő $C$ függelékre, melyet dr Lewis Mehl-Madrona munkájából vett át. Ebben átfogó, jól értelmezhető táblázatba rendezve tanulmányozhatjuk, hogy a kognitív elméleten túl milyen további magyarázó elméletek léteznek az autizmus kialakulásával kapcsolatban. Úgy gondoljuk, ez a fejezet jól összefoglalja az autizmussal kapcsolatos ismereteket.

A következő négy fejezetben az előzőekben felvázolt, az autizmus kialakulásának lehetséges okaként általában említett kognitív elméletek részletes bemutatását olvashatjuk. A negyedik fejezetben az elmeteória elméletét (ToM - theory of mind) ismerhetjük meg. Ez egy hagyományos elmélet a kognitív fejlődésről, melyet a neurotipikus gyermekek kognitív fejlődésének modelljeként dolgoztak ki Wimmer és Perner (1983) ötlete alapján. „A ToM az a kognitív mechanizmus az agyban, amely felelós a saját és mások elmeállapotának felismeréséért, illetve leképezéséért." (Lawson, 2018, p. 41). Az elméletet több kutató szemszögéből is megismerhetjük, majd a szerző összefoglalja a kutatók pró és kontra érveit azzal kapcsolatban, hogy milyen szerepe lehet az elmeteória elméletnek az autizmus kialakulásának magyarázatában.

Az ötödik fejezetben a Végrehajtó Funkció (EF - Executive Function) elméletével, ismerteti meg a szerző az olvasót. „az EF az összefoglaló neve az olyan funkcióknak, mint: tervezés, munkamemória, impulzuskontroll, és gátlás, valamint a cse- 
lekvés meginditása és ellenórzése" (Lawson, 2018, p. 66). Az elmélet definiálása után a fejezet az EF hiányosságával, illetve helytelen müködésével, mint az autizmus kialakulásának lehetséges magyarázatával foglalkozik.

A hatodik fejezetben egy újabb, az autizmus kialakulásának okaként felvetett kognitív elméletről, a Gyenge Központi Koherencia (WCC - Weak Central Coherence) elméletéről olvashatunk. „A gyenge központi koherencia, mint fogalom azt jelenti, hogy az élmények, részletek és egyéb információszeletkék nem állnak össze „teljes képpé’”' (Lawson, 2018, p. 79). A szerző úgy mutatja be ezt az elméletet, mint az autizmus kialakulásának egyik lehetséges magyarázatát.

A hetedik fejezetben a szerző az autizmus kialakulásának okaként emlegetett viszonylag új kognitív elmélet bemutatására vállalkozik. Ez a Túlfejlett Észlelési Funkcionalitás (EPF - Enhanced Perceptual Functioning) elmélete. Lawson (2018) ezt úgy definiálja: „Az EPF az agyban a különböző szenzoros és motoros információk túlzott feldolgozását jelenti, ami miatt bizonyos elemeket könnyebb „meglátni”, míg másokat nehezebb." (Lawson, 2018, p. 95). Az előző fejezetekhez hasonló alapossággal mutatja be Lawson ezen elmélet alapjait, hiányosságait és korlátait.

Az általánosan elfogadott elméletek részletes és kritikus ismertetése után a nyolcadik fejezetben Wenn Lawson saját Kognitív Elméletének bemutatására kerül sor. Ez az elmélet a Kizárólagos Figyelem és Kapcsolódó Gondolkodás Autizmusban elmélete (SAACA - Single Attention and Associated Cognition in Autism). A fejezetből megtudhatjuk, hogy a KFKG hogyan egészíti ki az előzőekben ismertetett négy elmélet hiányosságait. Abból indul ki, hogy az autizmust egy atipikus figyelmi stílus és a monotrópizmus, azaz a kizárólagos figyelem okozza. Ha az autista csak a monotropikus figyelmet tudja alkalmazni, akkor a hétköznapi fogalmak feldolgozásához korlátozott mennyiségű információja lesz. Tehát az autistáknak nem az elmeteóriájuk hiányzik, hanem az eltérő tanulási stílus miatt kevésbé férnek hozzá az 'én/másik' kapcsolathoz. A KFKG alapfelvetése, hogy bizonyos agyi funkciókkal bíró személyek más módon fognak tanulni, mint neurotipikus társaik. Míg az autizmussal nem érintett emberek mások viselkedésének észrevétele és utánzása révén tanulnak, addig az autisták nem veszik észre mások viselkedését, csak akkor, ha azok nagyon eltúlzottak, vagy valamiért felkeltik az érdeklődésüket. A KFKG tehát az autisztikus viselkedést a monotrópia következményeként magyarázza. A szerző által újonnan kifejlesztett elmélet szerint az autizmus egy „nagyon más” tanulási stílus, melyet a figyelmi-érdeklődési-szenzomotoros hurok típusostól eltérő működése hoz létre. Bár az elméletet még kevés empirikus 
bizonyíték támasztja alá, az autizmussal élők beszámolói alapján, illetve az idézett irodalmak szerint érdemes ebben az irányban tovább kutatni ezt a potenciális kognitív stílust. A szerző által leírtak alapján, ha a KFKG látásmódon keresztül viszonyulunk az autistákhoz és az igényeiknek megfelelő környezeti és oktatási erőforrásokat biztosítunk számukra, a figyelmi képességeik kiszélesedhetnek, és az 'én/másik' problematika jobb megértése is megvalósulhat. A kilencedik fejezetben az új elmélet gyakorlati jelentőségéről olvashatunk. Egyéni esettanulmányok bemutatásával világít rá az író elmélete mindennapi hasznosíthatóságára.

A könyv utolsó fejezete - mint ahogy a címe is mutatja - egyfajta jövőbe tekintés. A fejezet a könyvben szereplő gondolatok rövid összefoglalása, valamint az új elmélettől várt pozitív eredményeket vetíti előre.

A Wenn Lawson könyve véleményünk szerint hasznos összefoglaló mű az autizmus spektrum zavar iránt érdeklődők számára. A könyv olvasása közben megérthetjük, hogy „az autizmus nem elmebaj, hanem egy különleges gondolkodásmód, amely kihat a viselkedésre." (Lawson, 2018, p. 38). Tehát az autizmus spektrum zavar következtében kialakuló információfeldolgozási sajátosságok feltárása által az autizmussal élő emberek mélyebb megértéséhez visz közelebb bennünket. A könyvben említett, a tudomány által elfogadott vezető kognitív magyarázatok mögött nagyszámú empirikus bizonyíték áll. Az elmeteória deficit megnehezíti, gyakran ellehetetleníti, hogy az autizmussal élő emberek mentális állapotukból eredeztetve értelmezzék és bejósolják mások és maguk viselkedését. Emiatt a szociális világ kiszámíthatatlanná, szorongatóvá válhat számukra, továbbá reakcióik sem illeszkedhetnek a társadalmi normáknak elvárható módon a társas kontextusokhoz. A végrehajtó működések zavara gátolja a távolabbi célok elérését szolgáló, nem automatikus cselekvési sorok kivitelezését. Ez bármely szituációban okozhat elakadást, rugalmatlan viselkedésszervezést. Ezek mellett jellegzetes kognitív stílus az autizmusban a részletfókuszált észlelés, amely megnehezíti az ingerek kontextustól függő, jelentésteli egésszé szervezését, valamint a lényeges információk kiemelését.

A könyvből az is kiderül, hogy a korábban már kidolgozott, a témával foglalkozók számára jól ismert elméletek közül önmagában egyik sem tekinthető minden érintett számára, illetve minden esetben mindent megmagyarázó erejünek. A szerző által kidolgozott KFKG elmélet kiegészíti ezeket az elméleteket, vagy - fogalmazhatunk így - teljesebbé teszi azokat. Mivel ez az új elmélet túlmutat a már meglévő és elfogadott elméleteken, kijelenthetjük, hogy a könyv az autizmus 
spektrum zavar egy úttörő, újszerủ értelmezését nyitja meg előttünk, mely új elmélet középpontjában az egyéni figyelem és az azt társító kogníciók állnak. Megmutatja számunkra, hogy míg a neurotipikus emberek könnyen irányítják a figyelmüket egyik érdeklődési körről a másikra, addig az autizmussal élők egy témára képesek csak összpontosítani egyszerre, és még ez is nagyon intenzív figyelmet igényel részükről.

Úgy véljük, e könyv alapművé válhat az autizmussal élők családjainak, az újszerű meglátások iránt érdeklődő szakembereknek, valamint a téma iránt érdeklődőknek. Megpróbál alternatív magyarázatot adni az autizmus rejtélyére, és olyan együttműködési módokat felvázolni, amelyek egy olyan jövő vetítenek előre, amelyben minden autizmus spektrum képességeltéréssel élő ember reménykedik. Nagy segítséget nyújthat továbbá az olyan pedagógusoknak is, akik autizmus spektrum zavarral élő gyermeket nevelnek, tanítanak integráltan. A vonatkozó kutatások alapján a szakmai irányelvek óvodáskorban és iskolában egyaránt egyértelmủen támogatják az együttnevelést. Ugyanis vannak már tudományos bizonyítékok arra vonatkozóan, hogy az autizmus-specifikus támogatással megvalósuló együttnevelés pozitívan hat az autizmussal élő gyermekek, fiatalok fejlődésére. Ezért fontos, hogy a pedagógusok, akik autizmussal érintett gyermekeket nevelnek, tanítanak, kövessék az autizmuskutatások legfrissebb eredményeit. A könyvben olvasható elmélet újszerü megvilágításba helyezi az autizmussal élőkkel történő foglalkozás lehetőségeit. Segít megérteni, mi zajlik bizonyos helyzetekben egy autizmussal élő fejében. Ha pedig megértjük az ő szemszögéből a dolgokat, akkor hatékonyabban tudunk segítségére lenni a környezeti ingerek feldolgozásában. A könyvben bemutatott elmélet arra világít rá nagyon szemléletesen, hogy mivel az autisták neurobiológiai eltéréseik alapján másképp értelmezik az őket körülvevő világot, csak úgy lehet eredményes az integrálásuk, ha figyelembe vesszük az igényeiket. Mivel ők nem, vagy csak nehezen tudnak a neurotipikusok világához alkalmazkodni, a mi felelősségünk a környezet olyan kialakítása, melyben ki tudják bontakoztatni képességeiket. 


\section{Irodalom}

Bogár, V., Bíró, A. \& Marossy-Dévai, Z. (2009). Autizmussal diagnosztizált népesség a közfinanszírozott egészségügyi és a közoktatási rendszerben. In Petri, G. \& Vályi, R. (Eds.), Autizmus-Tény-Képek (pp. 7-110). Autisták Országos Szövetsége és Jelenkutató Alapítvány.

Emberi Erőforrások Minisztériuma - Egészségügyért Felelős Államtitkárság (2020).

Egészségügyi szakmai irányelv - Az Autizmusról/Autizmus spektrum zavarokról. Egészségügyi Közlöny, LXX. ÉVFOLYAM, 12. szám.

Fombonne, E. (2005). The changing epidemiology of autism. Journal of Applied Research in Intellectual Disabilities, 18(4), 281-294.

Lawson, W. (2018). A szenvedélyes elme. Geobook Hungary Kiadó

Oktatási Hivatal (2018). Közoktatási információs rendszer (KIR).

Wimmer, H. \& Perner, J. (1983). Beliefs about beliefs: Representation and constraining function of wrong beliefs in young children's understanding of deception. Cognition 13, 103-128.

\section{Internetes források}

Autisták Országos szövetsége/ Az autizmusról URL http://aosz.hu/az-autizmusrol/ (2020. 09. 16.)

Dr. Wenn Lawson's Website ULR http://www.buildsomethingpositive.com/wenn/ (2020. 03. 20.) 